\title{
Who 'We' are and How We Perceive 'Others': Influence of History Textbooks During the Construction Process of 'Self' and the 'Other' in Cyprus
}

\author{
Assist. Prof. Dr. Tutku Akter \\ Girne Amerikan University
}

\begin{abstract}
The construction of knowledge cannot be examined without the influences of power relations and its ideological instrument; discourse. However, interpretation of given information despite of discourses by the recipients also play an important role at knowledge/identity construction. During the study the indictment of the idea that "missing information about the 'Other' and the words for identifying the 'Other' may cause biased national discourses" is assumed. The study is focused on Cyprus Island, which is divided into two parts and shelters two communities. These communities share certain periods of the past but expressed by different discourses in the history textbooks. The purpose is to figure out whether the history textbooks were influential on the construction of the I'selfl' and the I'Otherl'. To illustrate whether citizens of both republics are active recipients or passive one; a questionnaire has been delivered to 100 Turkish and 100 Greek Cypriots who live in the island.
\end{abstract}

Keywords-identification, knowledge, history textbooks, Cyprus.

\section{Introduction}

For if 'doing history is about how you can read and make sense of past and the present', then it seems important to me to use discourses that have 'readings' and the construction of meanings as major concerns. (Jenkins, 2006)

The invention of printing had and still has certain gains just like the discovery of written communication. The construction of individualism and nationalism can be accepted as one of these gains. The concept of nationalism and printed books cannot be separated from each other because, if books were not printed, the concept of nationalism would not have occurred (McQuail, 1994). With the help of the printed media, people were able to observe themselves, evaluate their pasts and imagine or think about their future.

By the rapid development of communication technologies, new questions related to the society-mass media interrelation such as 'who controls the mass media?', 'how do they use 
it?', 'for what purposes?' etc. also arouse. It is possible to claim that new communication technologies could bring new risks with it. One of the methods for investigating the socioeconomic, cultural and political consequences of the rapid development of mass media is examining the influence of the constructed language that is used as a mean of communication.

Language has the power to dominate, construct or re-construct everything in our lives, including ourselves. We are surrounded by such a system that involves everything both related and unrelated to 'us'. Therefore, it is necessary to recognize the power of language within this system to understand 'the World'. In order to examine the power of the structured languages thus the 'discourses' of written materials in the 'construction of knowledge' process, history books can be analyzed.

The history of a country is a kind of guide, which constructs the identity of the country in question. History can be explained as the past and also as an account of the past. (Newall, 2005). History as the past, involves the past "seem to be just past: what happened before, whether in a specific period or just generally before now". Newall also handled history as the 'true' account of the past, and the correspondence between what actually happened in the past and an account of it. However, history and the recording of history is quite different from the 'Past' (Jenkins, 2006). The 'Past' is constructed through the facts that have happened and cannot be lived once again. On the other hand, in history and recording of history some of the facts and their discourses are explored.

History (thus recording history) can be assumed as a discourse about the past and cannot reflect the past as it happened. Historians deal with evidence they obtain but they construct their own discourses through the data at hand. Therefore some questions should be raised such as 'what is the purpose of history', 'whose history is this' and 'what is it for'. Newall listed the purposes of history as 'for its own sake', 'to find out the truth about the past', 'to try to understand where we came from', 'to try to understand why a particular event happened', 'to find out historical laws' and 'to justify actions in the present '(Newall, 2005).

Therefore, while de-constructing some historical events, it is necessary to draw attention to the different versions of the same event and to note the differences between the discourses of each, in order to understand the ideology of the records. It is also essential to question whether 
there are big knowledge gaps between each of the records. If there are, it is necessary to rethink about the history or the concept that we accept as history. For the purpose of the study Cyprus history textbooks that are studied in the secondary schools of both Northern and Southern Cyprus are examined. Because of the fact that these books were re-printed by the changing governments, the first one which was re-printed by the recent governments of each region is observed. To illuminate this, the first edition of the Cyprus History text books, which is published by the present government of the Northern Cyprus, and the last edition of the Cyprus History text books that are studied in the secondary schools of both of Northern Cyprus and Southern Cyprus are examined. During this observation and analyzing process another question was arisen and became subject matter of the present study: "effectiveness of these books at the construction of 'self' and the 'Other'".

Making different histories, despite sharing the same past may change the construction of 'I' and the 'Other' via the knowledge that is legitimated through the changing discourses. The possibility of writing the same history about the shared past may make the 'I' and the 'Other' concepts as the stable subject. This is in parallel with the possibility of knowledge, which constructs the national identity that is legitimated via the same discourses.

Consequently, the interrelation between language (discourses), written history, sense of nationalism, books (as a mean of mass media) and construction of national identities can be summarized as follow 


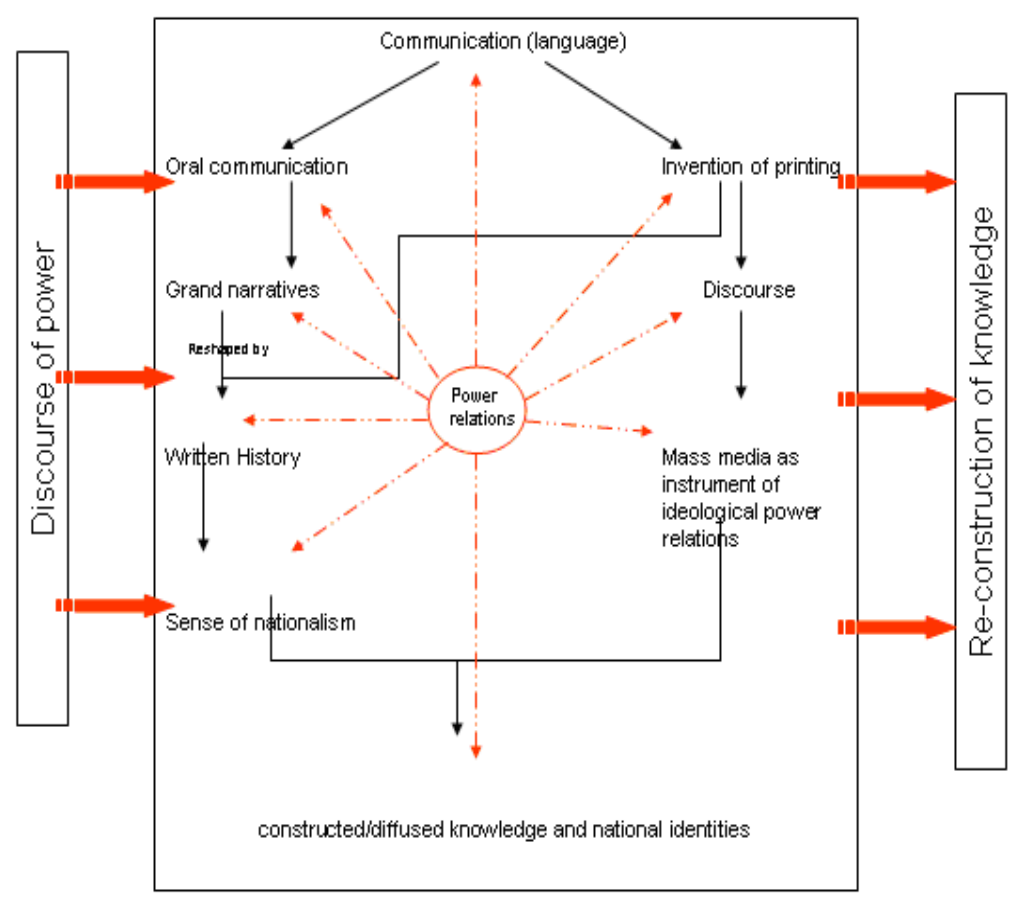

Fig 1. (Akter, 2009).

\section{How Influential can the History Textbooks be on Construction Identities?}

In the study of the media effects, its history and constitution of its influences, the empirical approach is ".....characterized by quantitative methods and empiricism. It has often focused on the effects of mass communication, while disregarding the broader cultural context in which mass communication takes place" (Severin \& Tankard 2001). This approach insisted on emphasizing the significance of measurable, observable and quantifiable evidences of the mass media. That is to say this approach focuses on the effects of the communication systems.

The critical approach "takes a more philosophical approach, emphasizes the broader social structure in which communication takes place, and focuses on the issue of who controls a communication system" (Severin \& Tankard 2001). This approach focuses especially on the owner of the communication system and the way of controlling it. It is about questioning the media organizations about how/why they came to be and how/for whose benefits they are working. So it is essential to claim the interrelation between ideology and the power of the media owners and the diffusion of the process of knowledge.

The present study, while focusing on Cyprus history textbooks studied in secondary schools, tries to emphasize the necessity of rethinking what we know as history and our knowledge 
about the past. In other words the significance of the present study is to show 'how to know what we know' and 'how to be sure whether the knowledge that we have is ours' or 'the one that is naturalised as if ours'.

History, which can be explained as the re-construction of the past via the related monuments are obtained by the historians. Therefore talking about the objectivity or unconditional certainty of what historians have mentioned (history), would be as problematical as claiming the objectivity of the flow of information via the mass media.

As it is mentioned above this study is focused on Cyprus Island, which is in the middle of the Mediterranean Sea and is located 40 miles south of Turkey. It is part of the histories of several nations due to its geographical and strategic significance. This island is divided into two parts and shelters two communities. These communities share certain periods of the past but expressed by different discourses in the history textbooks.

In Cyprus, all of the information students get, is built on the information given to them in secondary schools because it is the first time that they are introduced to history during their education. Meanings, as Belsey and Moore (Belsey \& Moore 1997) also mentioned, "are cultural, and learned, though we learn them so young that they seem to be there by nature".

A sense of identity is developed during the adolescence period. This period is also associated with puberty. The period of puberty is roughly equivalent to the 10-12 ages for girls and 12-14 ages for boys which is equivalent to the secondary school period. Ages between 10 and 14 can be assumed as the most important period in the development of personality in the sense of identity. Within this period adolescents begin to question 'who they are', 'what they believe', 'what is the purpose of their lives' etc. Moreover they develop their sense of identity via personal values and adapted social behaviour. Therefore it is necessary to consider years of secondary school at length especially understanding the identity construction process of youths. During these years, the information that is given to them, experiences they have as well as events that are monitored from the close environment should be examined carefully.

There are various communication theories claimed that communication means, which is considered as the ideological guns of the owners of the institutions or the owners of the 
ideologies, influencing the audiences about what to think and how to think about what is given. However, as well as the ideological perspectives of the owners of the mean of communication, it is necessary to explore whether readers/audiences are active recipients or not. Thus, by carrying out such a research, how influential history textbooks are on students about constructing 'self' and the 'Other' is tried to be clarified via questionnaires.

During the present study whether 'defining 'self' refer to how 'others' are defined or not', whether 'defining 'others' give information about the political view about the current situation or not' is figured out. In addition to this whether media and Schools (thus books) play an important role in the process of defining 'the other' or not, whether history textbooks play an important role in the process of defining the other or not, whether defining the other is interrelated with how they assume others define them or not and whether readers of history textbooks are passive recipients that are not aware of being influenced or not is explored.

\section{How to be an Active or Passive Recipient?}

It is possible to talk about several approaches in the field of communication studies; these approaches differentiate from each other especially by the definitions of some concepts such as recipient. While some of them, such as in uses and gratification theory, the active roles of viewers are stressed in choosing "what media to "consume" and in interpreting the content of messages in accordance with their own interests, needs, and fantasies." (Oskamp \& Schults 2005), for some others which took media as the sociological object with the individual as their psychological subject, it is claimed that rather than its readers, the media is assumed as active (Scannell, 2007).

As cited in Hiebert and Gibbons, McQuail (McQuail, 1994) categorized audience-reader relationship in three groups; passive audiences, active audiences and passive-active audiences. Through this the most helpless ones are accepted as the passive spectator audiences. Passive spectator audiences are the one who are hypnotized by the mass-mediated messages, their weaknesses and prejudices are exploited by the messages. Besides, the way they think about the message is determined by the media technology and their national and cultural boundaries are broken down by communication flow. These types of audiences use media without processing the messages and became helpless victims by the increased subtlety and sophistication of persuasive communication (Hiebert \& Gibbons 2000). 
Active participant audiences are "made up of individuals with their own lives and histories and social networks" (Scannell, 2007). As authors claimed, three ways in which audiences are increasingly seen as active is suggested by the recent researches. Due to these researches, the meanings of media messages are built by audiences via an active engagement of audiences with text. Besides this, it is assumed that because audiences don't follow media in a vacuum, collective interpretation takes place and it is also noted that where "audiences take formal and public stands on media productions, both positive and negative, making demands or seeking corrections or additions" (Scannell, 2007), collective action occurs.

Passive- active audiences are the ones which are accepted as targets of commodities. It is assumed that most of producers of mass communication share this view. Due to this view, audiences are assumed as an entity "a package, and a price is placed on that package depending on its size, its quality and the quality of the media content that creates the audience in the first place. In other words, "the notion of an "audience commodity" relies, of course, on the related concept of "audiences as consumers" (Hiebert \& Gibbons 2000).

\section{Glance at Cyprus and Cyprus History Textbooks}

As mentioned above the very starting point of this study was the discourse and the content of the Cyprus History textbooks that are studied in the secondary schools at both parts of the island. Cyprus Island which shelters two communities is colonized by several empires and civilizations. From 1489 to1571 the island was under control of Venice, then Ottoman Empires' up to 1878. In 1878 it is chartered to British dominance. Finally in 1960's Cyprus Republic is established. Within this Republic, Greet Cypriots were forming the majority of the population and Turkish Cypriots were minority. However, uncompromising attitudes of both nations broke out in the mid of 1960's so much that Turkey as one of the guarantor governments interfered and took Turkish Cypriot cover by moving them to the Northern part of the island in 1974. The rightness or the consequences of this interfere is not subject matter of the study, but the 'injected' prejudices/ideas/knowledge about the other via the history textbooks and their influences on the citizens of both communities are studied.

Throughout the results of the discourse and content analyses of the texts it is clear that 
changing powers brought their different discourses with themselves. Due to this the definitions of 'I' and the 'Other' concepts could never overlap, as mentioned before, even it is referring to the same/ common event(s). Comparative study of the content analysis indicated that the text books are not equivalent with each other. While North Cyprus history text books gave information in 35 pages, South Cyprus History Text Books (D'Acci, 1994) informing students about the events that had happened after 1960 in four pages. Picturing and caricaturizing the events in the books of Northern Cyprus (YAP, 2006) are more 'pacifist' than the one which is studied in the secondary schools of Southern Cyprus is the another point that is noticed.

Both of the nations accept the existence of the 'Other' nation as a partner and identify each other as 'Greek/Turkish Cypriots' but the words, which are selected by 'Turkish Cypriots' in order to express themselves, are more filtered.

Influences on the discourses of the texts by the dominant power relations and the dominant political party are clearly noticed during the the comparative results of the critical discourse analysis of the history textbooks that are studied in the secondary schools of both Northern and Southern Cyprus. As a result of this, it is possible to claim that changing discourses leads changes at the construction of knowledge about 'I' and the 'Other'.

\section{How Influential is the Materials Read by Citizens are?}

As it is mentioned before, questionnaires, which include 17 close ended multiple choice questions, are conducted to 100 Turkish and 100 Greek Cypriots who live in Cyprus. 54 of 100 'Turkish Cypriot' respondents were male while 36 of 100 Greek Cypriot respondents were male. Within 100 'Turkish Cypriot' respondents \% 55 were born before 1974 and within 100 'Greek Cypriot' respondents \% 54 were born before 1974. Due to this majority of the respondents in both of the sample groups born before 1974 operation that is done by Turkey as guarantor government.

Within 'Turkish Cypriot' respondents, 69 identified themselves as Turkish Cypriots, 61 identified people, who live in the South of the island, as Greek Cypriots. Beside this 59 of these respondents described them as neighbours but 41 of them think 'Greek Cypriots' describe them as enemies. According to the result of the survey conducted to the Southern Cyprus, 47 of 100 respondents identified themselves as Greek Cypriots, while 61 of them 
identified people who live in the Northern part of the island as Turkish Cypriot. 33 of 100 Greek Cypriot respondents described Turkish Cypriots as neighbours while 33 think they are described as the 'Other' by Turkish Cypriots.

In comparison to results it is clear that Turkish Cypriots are more willing to describe Greek Cypriots as neighbours. However respondents of both sides of Island have prejudice about being described by other nation.

48 of Turkish Cypriot respondents declared family and close friends as the primary source of information while 28 of them as the experiences that they had and 20 respondents' primary source of information is noticed as school textbooks and media. On the other hand 44 of Greek Cypriot respondents stated experiences that they had as their primary source of information, 30 respondents' primary source of information is noticed as school textbooks and media while 26 of 100 respondents noticed their family and close friends as their source of information. Due to this, it is clear that experiences that they had are more influential for Greek Cypriots at the construction of their knowledge about Turkish Cypriots, while families and close friends are more likely influential for Turkish Cypriots on their knowledge about Greek Cypriots.

As well as exploring their identifications and primary source of information, their views about the history textbooks are investigated. The purpose of examining their views is to figure out their awareness about the information that is involved as well as their prejudices about other nation's history textbooks. Throughout the results of the survey that is conducted, 55 of 100 Turkish Cypriot respondent do not believe that "Cyprus History Text Books" that are studied in the secondary schools involve enough information while 45 of them think they are identified as enemies in "Cyprus History Text Books" that are studied in the secondary schools in the Southern Cyprus . On the other hand 37 of 100 Greek Cypriots do believe (even if partly) that "Cyprus History Text Books" that are studied in the secondary schools involve enough information, while 43 of them do not have any idea about how they are identified "Cyprus History Text Books" that are studied in the secondary schools in the Northern Cyprus. 40 of 100 Turkish Cypriot respondents and 50 of 100 Greek Cypriots think they are influenced by the information that is written about people who live in other part of the island. Thus, it is clear that respondents are not literally passive recipients because of being aware of 
the fact that they are influenced by the given information.

During the present study ages of the respondents are handled as one of the dependent variables. Respondents who were born after 1974 are the one who never lived together as citizens of the same government. Therefore living together with other community is assumed as the indicator of changing ideas, identifications and prejudices during the present study.

According to the survey that is conducted to Turkish Cypriots, most of the respondents who were born both before 1974 and after 1974 think that people who live in the South of the island describe them as 'enemy'. In addition to this, they define people who live in the South of the island as 'neighbours'. However within people who defined them as 'enemies' mostly are respondents who were born after 1974 .

Most of the respondents who were born both before and after 1974 identify themselves as Turkish Cypriot and people who live in the South of the island as Greek Cypriot. However the new generation who were born after 1974 are more willing to identify themselves and people who live in the South of the island as Cypriot, so they are a bit more defender of 'Cypriotism'

Throughout the survey that is conducted to Greek Cypriots, most of the respondents who were born both before 1974 and after 1974 identified themselves as 'Greek Cypriot', the majority identified people who live in the North of the island as 'Turkish Cypriot'. The majority of respondents who identified themselves as 'Cypriot' were born after 1974 as in the results of survey that is conducted to Turkish Cypriots. This kind of identification by respondents who born after 1974 might be result of not experiencing the past as the ones who born before 1974 had.

What the respondents think about the current political situation of the island also explored during the present study. It is noticed that Turkish Cypriot respondents both born before and after 1974 think that living together is not possible. Thus, they mostly approve the division of the island. Nevertheless, they wished to live in Bi-communal Federate State, in stead of the

1 Cypriotism is an ideology that stands in opposition to the nationalist ideologies that consider Cyprus as the extension of Greece and Turkey. (MEKB, 2004) 
current situation of the island. So they are not fine enough with the current situation, but mostly they do not want to live together with the people who live in the South of the island.

According to the results of the questionnaires Greek Cypriot respondents who both born before and after 1974 think that they need to live together with Turkish Cypriots. Thus, unlike Turkish Cypriots, they mostly disagree about the division of the island. In stead of the current situation of the island, they wished to live in a single state. So they are not fine enough with the current situation. Moreover they mostly want to live together with the people who live in the Northern Cyprus.

For both of the Turkish Cypriot respondents who were born before and after 1974, the primary source of information is their families and close friends. Majority of these respondents who got the information/ knowledge from the school text-books are the ones who were born after 1974 operation as it is assumed before. The majority of the respondents who were born before the 1974 operation accepted the partly influence of the given information on them. Those respondents who were born after the 1974 operation refused the influence of the given information in the secondary school text books that are studied.

Finally according to the results of the survey that is conducted to the Southern Cyprus, the primary source of information is families and close friends of the respondents who were born after 1974. For respondents who were born before 1974, the primary source of information is the experiences that they had. The majority of the respondents who got the information/ knowledge from school text-books are the ones who were born before 1974 operation. Withal, there is no clear distinction between respondents who were born before the 1974 operation and after about accepting the influence of the information that is given to them in secondary school text books.

\section{Conclusion}

For the purpose of the study, to find out the awareness of the respondents about the influence of the information that was given to them, 17 close ended questions conducted to 100 Turkish Cypriots and 100 Greek Cypriots. During the research, whether the readers are passive or active recipients of the given information was tried to be discovered. Furthermore, via the survey that is conducted, differences between the ideologies of the dominant parties 
(government) of each side were exposed. Also consensus of the communities of each state about the one who live at the other side of the island, the situation and diplomacy was clarified.

Through the results of the questionnaires it was clarified that communities of the both states identify each other as 'Turkish/Greek Cypriots'. Thus it is possible to claim that both of the nations accepts the existence of the 'other' nation as their associate about island that they live in. Both of the nations define each other as 'neighbours' but 'Turkish Cypriots' that they are defined as 'enemies' while 'Greek Cypriots' thinking that they are defined as the 'Other'. This finding shows that somehow both of the nations are prejudiced about being defined by other nation. Beside this 'Turkish Cypriots' think it is not possible to live together but 'Greek Cypriots' think that they need to live in a single state. One of the most important findings of the questionnaire that 'mass media' and 'school text books' are last information source that both of the communities confer with. This may indicate that the respondents (thus community members of each nation) are passive recipients of the information that is given to them. However they (respondents of both sides) agree with the fact that the school textbooks that are studied in the secondary schools do not involve enough information. Finally according to the results of the questionnaires, majority of the respondents of both sides believe in necessity of writing the common history textbook and believe that this kind of study may form more moderated representations.

To sum up, during the present study it is noted that history textbooks that are studied in secondary schools of both of the regions are not literally influential at the construction process of knowledge and identity. Awareness of the recipients about the lack of information of the textbooks can be assumed as reason of not being fully passive recipients. Moreover, the prejudice of both of nations about 'being identified' by other nation, despite of identifying and describing them with 'pacifist/conciliatory' discourses is legitimated during the present study.

\section{References}

Akter, T. (2009). Knowledge as the victim of negotiation: an exploratory study of the national identity construction in the Cyprus history textbooks. (Ph.D. dissertation). Girne American University. p 6

Belsey, C., \& Moore, J. (1997). The story so far. In Belsey, C., \& Moore, J. (Eds.). The 
feminist reader. (pp. 1-20). Hong Kong: Macmillan. p 4-5

D'Acci, J. (1994). Defining Women: television and the case of Cagney \& Lacey. The University of North Carolina Press: USA. p 65

Hiebert, R. E. \& Gibbons, S. J., (2000). Exploring Mass Media for Changing World. Routledge. p 118

Jenkins, K. (2006). Re-thinking History. ( $5^{\text {th }}$ Edition) Oxford: Routledge Classics. p 4 Madianou, M., (2005). Mediating the nation: news, audiences and the politics of identity. Cavendish Publication: London

McQuail, D. (1994). Mass Communication Theory. $3^{\text {rd }}$ Edition. London, Thousand, New Delhi: Sage Publications.

MEKB, (2004). Kibris Tarihi [Cyprus History]. Nicosia: Milli Egitim ve Kultur Bakanligi. URL: http://www.mebnet.net/Kitaplar/Tarih3.htm

Newall, P. (2005). Philosophy of History. Http://www.galilean-library.org/int18.html

Oskamp, S. \& Schults, P.W., (2005). Attitudes and opinions. $3^{\text {rd }}$ Edition. Lawrence Erlbaum Associates, Inc.: New Jersey. p 184

Scannell, P. (2007). Media and Communication. Sage: London

Severin W. J. \& Tankard J. W. JR. (2001). Communication Theories: Origins, Methods, and Uses in the Mass Media. New York: Longman Publications. p 15-16 YAP, (2006). Istoria tis Kyprou-Romaiki [History of Cyprus, Neolitik-Roman]. Nicosia: Ypiresia Anaptyxis Programmation. 